\title{
The Rise and Fall of Curriculum 2013: Insights on the Attitude Assessment from Practicing Teachers
}

\author{
Yuliana Natsir, Yunisrina Qismullah Yusuf*, Ulva Fiolina Nasution \\ Department of English Education, Faculty of Teacher Training and Education, Syiah Kuala \\ University, Banda Aceh 23111, Indonesia
}

\begin{abstract}
The change of Indonesia's national curriculum from SchoolBased Curriculum 2006 (hereafter SBC 2006) to Curriculum 2013 (hereafter CR 2013) has caused modifications in the assessment system which requires teachers to use authentic assessment. Many teachers are facing setbacks in the implementation of this assessment, particularly in the attitude aspect. This qualitative research mainly focused on investigating the problems in conducting the attitude assessment faced by teachers in CR 2013. Three English teachers from three junior high schools in Banda Aceh were selected and interviewed with questions adapted from Handayani (2014) and Eliza (2015). The document analysis of attitude assessment was also done to see the reports of students' attitudes. The findings showed that the teachers knew the importance of authentic assessment as a necessity for assessing students' learning outcomes in CR 2013, but they admitted that it was complicated since many categories need to be assessed in detail. They find it impossible to assess all of the students in every school day. When parents do not want to cooperate if their children are in need of attention from both parents and teachers, it is also an obstacle for the teachers to do the assessments. Furthermore, the teachers deemed that self- and peer-assessment were ineffective and the paper further discusses why it is so.
\end{abstract}

Keywords: Curriculum 2013, assessment, attitude aspect, challenges, teachers

\section{Introduction}

Along with demands from the era of development, science and technology, the changes of curriculum from time to time in Indonesia is a phenomenon that cannot be avoided in education. A curriculum can only be good for a particular community at a particular time [1]. The occurrence of the curriculum change in Indonesia has begun since 1984 until now. The continuous change requires Indonesia to create future generations with strong national

*Corresponding author: yunisrina.q.yusuf@unsyiah.ac.id 
identity, being able to compete and adjust to the global changes. Education should be capable of producing human resources that have the competence of being competitive, innovative, creative, collaborative, and with good characters ${ }^{[2]}$.

Curriculum 2013 (hereafter, CR 2013) is the recent curriculum Indonesia which was created to complement the previous curriculum, which is School-Based Curriculum in 2006 (hereafter, SBC 2006). CR 2013 has the aim to encourage learners to become individuals who are able to conduct observation, questioning, reasoning, and communication that they have acquired during the learning processes in schools ${ }^{[3]}$. In relation to the implementation of CR 2013, there are two fundamental changes found, namely the change in the learning system and the change in the assessment system ${ }^{[2]}$. Since this paper focuses on the assessment system, therefore, the discussion revolves around this assessment.

CR 2013 emphasizes on authentic assessments which includes the self-assessment, project assessment, portfolio assessment, process assessment, and performance assessment. The assessment is changed from the knowledge-based to the change-based and is done through process, portfolio, and full and complete output assessment ${ }^{[3]}$. Hence, the authentic assessment can measure and evaluate the learning outcomes of a student as a whole, both from the aspect of attitude, knowledge, and skill ${ }^{[4]}$. Moreover, this assessment was also proposed by Wiggins ${ }^{[5]}$ in which it is a form of task which requires the learner to show the meaningful real-world performance.

Nevertheless, the application of this curriculum still rises with various controversies. Alawiyah finds the preparation of CR 2013 was considered too hasty and did not refer to the result of studies that have been done based on the evaluation of SBC 2006, as well as less attention to the readiness of the education unit and the teachers ${ }^{[6]}$. Maghfirah also finds that the time available for the teachers to conduct the assessment is not sufficient considering other workloads that they need to do in school ${ }^{[7]}$.

In the previous curriculum, the attitude assessment received less attention so it was deemed ineffective by the Ministry of Education. There were scores given by teachers that had gaps between students' report cards and their daily behaviors. Thus, in CR 2013, teachers who were typically accustomed to cultivate the value only in the aspects of knowledge and skill are now required to also pay attention to the aspect of attitude. The attitude competence in CR 2013 is divided into two, namely the spiritual attitude (KI-1) and social attitude (KI-2). Teachers are to assess the students' attitudes through observation, self-assessment, peer-assessment (by using check lists or rating scales of a rubric), and journals (in the form of teachers' notes). Many teachers are still not ready with this system since it is different from the previous curriculum ${ }^{[7][8][9]}$.

From our preliminary discussion with some English teachers in a couple of junior high schools in Banda Aceh, it was also found that the teacher guideline book (buku petunjuk guru) did not provide sufficient information for them to apply the authentic assessment of the attitude aspect. This is also agreed by Bhakti, Kusairi, and Muhardjito ${ }^{[10]}$ who also found that the guidance for teachers was not sufficient to provide understanding of the application. And so, we are interested to further investigate the problems faced by English teachers in implementing authentic assessment of the attitude aspect in CR 2013. Thus, the research question for this study is: "What are the problems faced by English teachers in the process of attitude assessment based on Curriculum 2013?"

The research result is expected to give more input, knowledge, and reference in improving the quality of education in Indonesia in implementing Curriculum 2013, particularly in the process of authentic assessment. It is also expected to contribute positively to English teachers to be better and conscious in assessing the students' attitude, so that the process of teaching and learning can be carried out optimally. 


\section{Methodology}

This research is qualitative with a case study approach. It was conducted in three public junior high schools in Banda Aceh, namely SMPN 1, SMPN 2, and SMPN 6 since the teachers at those schools have been implementing CR 2013 in teaching English. One English teacher was chosen from each school based on their consent, and thus, making a total of three respondents for this research.

Two instruments were utilized in collecting data, namely interview and document analysis. The interview questions are adopted and modified from the interview guide by Handayani ${ }^{[9]}$ and Eliza ${ }^{[8]}$. There were nine main questions, with one question that consisted of 3 sub-questions. The questions revolved around the implementation and the problems teachers' faced in conducting the authentic assessment on the attitude aspects. Each teacher was interviewed and audio recorded with a cellphone for about half an hour. This was done after their school time was over. The interview was conducted in Indonesian language and the results were transcribed and translated into English. Moreover, the data from documentation is the students' attitude assessments compiled by the English teachers during the process of teaching and learning. The data from these documents were studied and used to obtain information related to the attitude assessment process.

Data analysis in this research followed the model suggested by Miles and Huberman ${ }^{[11]}$, namely data reduction, data display, and conclusion drawing/verification.

\section{Results and Discussion}

The first question that we asked was about the suitability between authentic assessment in the attitude aspect and the learning process. The opinion of the teacher can be seen below (E refers to excerpt and $\mathrm{T}$ refer to teacher):

E1 Yes, it is. It depends on the learning process that has been done by each teacher. For example, if the teacher uses the scientific learning approach as suggested by the curriculum, then she must also use authentic assessment for the students' attitudes. (T2)

$\mathrm{T} 1, \mathrm{~T} 2$, and $\mathrm{T} 3$ considered that the application of teaching and learning process in schools was in accordance with authentic assessment in the attitude aspect because the assessment must be related to the students' reality, or in other words, everyday behavior and attitude.

The second question consisted of three sub-questions that inquired about the obstacles that the teachers found in the assessment. There are three aspects in the authentic assessment, namely attitude, skill, and knowledge that have to be done by the teachers. The first and second sub-question was about the difficulties they faced while implementing the three aspects.

E2 There are too many things to be assessed for every single student on every school day. Besides this assessment on attitude, I also have to continue on the evaluation of the skill and knowledge aspects for every single student. Along the way, the learning process has to be done, too. Sometimes I assess each student, but not at the same time, not in one day. We cannot do it all; the workload is a bit overwhelming. Indeed, we are expected to do them all, but in reality, we cannot achieve everything in one day. (T3)

Similar to T3, T1 also experienced the difficulties when conducting the assessment. Her class consisted of 35 students in one class; due to this large classroom, the time was insufficient to assess each of them while teaching at the same time. There were other activities that also needed to be dome besides making assessments, such as making lesson plans, preparing materials, and so on. 
For the last second sub-question, we inquired about the most difficult aspect in the implementation of authentic assessment. T1 elaborated her answer as:

E3 Of course, the attitude aspect! We know there are two kinds of attitude assessments; they are selfassessment and peer-assessment. The problems in these two assessments are honesty and trust. Sometimes, I find that when the students do the self-assessment, they are not honest. For example, a student said that he never cheated in a test, but I have found him doing so a few times. While in the peer-assessment, they may be worried if they give bad assessment for their friends, they will lose friends. So they write all nice things about each other. However, it can be a lesson for teachers to see whether a student is honest or not. We can judge it from their assessments. (T1)

Based on E3, T1 as well as the other teachers claimed that attitude assessment was the most challenging one to conduct. Apart from that, T2 believed that the assessments on the skill and knowledge aspects are not as difficult as the attitude one because they are evidently reflected through scores from the students' test results and school work. But the solid challenge is facing the parents; T2 realized that when it comes to students' discipline, some parents often interfered and denied their children's faults. Thus, to gain this kind of parents' cooperation in fostering the children's discipline could be wearisome.

The third question asked teachers' opinion about the process and rule of authentic assessment in CR 2013, whether they agreed to it or not. T3 enlightened:

E4 I agree but it is too much. I mean, I hope it can be more simplified so that teachers are not burdened with all of the detailed assessments for every student. With our work load, it is impossible! I hope the policy makers can make consideration of this situation so that we can teach more effectively. Otherwise, the assessments will be ineffective if we cannot teach to our fullest capacity. (T3)

All of the teachers actually agree about the process and rule of authentic assessment in CR 2013, nevertheless, T1 and T3 saw it as too much of a burden for teachers to do everything with the work load that they also have in school besides making assessments. The explanation by $\mathrm{T} 3$ can be implied that the process is time consuming, whereas in the previous curriculum the teacher supposed to focus more on teaching materials.

The fourth question was related to the teachers' views in assessing students' learning outcomes through the attitude aspect, whether it is necessary or not. The following statements described their views.

E5 Even though it is too much, but, yes, it is necessary. This attitude assessment is good, because it can improve the students' characters. Sometimes the students will improve their attitude when they know I am assessing them in that aspect. Although they may feel forced to do good things at first, but I believe, sooner or later they will be accustomed to them, right? (T1)

All of teachers say that attitude assessment is important because as T1 said, the students would behave well when they knew that their attitudes were being assessed by the teachers. Perhaps they may felt forced at first but T1 believed that the driven attitudes would later become habitual to the students. T2 and T3 further added that the role of teachers is not only to teach, but also to educate and to guide students to become virtuous individuals.

The fifth question probed about the things that must be considered in the process of attitude assessment. One of the answers from the teachers can be seen as follows.

E6 In the attitude assessment process, I am most concerned about the observation and journal since the peerassessment is not effective. So, to me, the most important thing is when I observe them personally. This is where I directly see how the students act. If after I access them and their scores are still low, I will remind them. It means that they should try to change to be better. If I do not care, the students will continue making mistakes. (T3) 
Regardless of being overwhelmed with the attitude assessment in CR 2013, the teachers agreed that observation and journals were essentials because they provide direct assessment to students' attitudes. The observation was also considered more effective than selfassessment or peer-assessment. Yet, they also respect the self- and peer-assessments because they could become benchmarks for the teachers' assessments.

For the sixth question, it revolved around the way the teachers assessed students' learning outcomes based on the attitude aspect and time of assessment.

E7 When I enter the classroom, I must be prepared with various assessment formats, especially the attitude aspect. I do the attitude assessment while I am teaching, I give the materials, and when I am finished, I monitor and assess the students directly as I walk around the classroom. For example, there was a student who had a problem in learning, so I wrote it all down in in my note. It is overwhelming, especially when we have a large class. (T1)

Here, the teacher already knew how to assess students' learning outcomes in the attitude aspect. It was done for every student in every meeting and overwhelming to the teachers. Thus, T1 suggested should this kind of assessment is done to a small class; the efficiency would be more optimal.

The seventh question was related to the teachers' obstacles in assessing the attitude aspect. The writer asked the teachers about the problem that might happened during the implementation of attitude assessment. The following statements are their opinions.

E8 Yes, of course there are obstacles. In the authentic assessment, I get directly involved with the students. They may misbehave one or two or three times. Sometimes I do not know what to do. Sometimes when I called their parents, they did not come. It is a little bit difficult for me. (T2)

The teacher's elucidation in E8 revealed her difficulties in conducting the attitude assessment. It is when there were parents who did not want to cooperate with them when they needed assistance in improving the students' unpleasant attitudes. T1 and T3 added that when these attitudes were rooted from other factors outside of school; the assessment then become more difficult to grade.

Aside from asking questions about the attitude assessment, investigating about their participation in training or seminar concerning CR 2013 was also queried. T2 explained:

E9 I have attended workshops on CR 13. I was also given a module to assess students' learning outcomes. Although it was complicated, I have studied it all, how to assess the knowledge aspect, and the skill aspect with the portfolio, as well as the attitude aspect, with each instrument. (T2)

All teachers informed that they had attended workshops on CR 13 and knew the differences between this curriculum and the previous one, SBC 2006. They also understood on how to do the assessment and learning process based on the outcomes they achieved from the training.

Finally, the last questioned probed about the guideline of assessment process, whether they received it or not while they took their trainings on CR 13. T3 revealed that:

E10 Yes, I have it. But, as far as I know, this assessment is said to be changed again, because it is too complicated for many teachers. Perhaps, they will conduct training again about the new assessment. Personally, I suggest the policy makers to test all rules and policies really well first before instructing all teachers to implement them. If not, we teachers will be the victims of rules that changes all the time. (T3)

Based on E10, all teachers confirmed they were given the guideline. Thus, T3 still found it complicated. She also added that even though trial and error is common, but to seriously test out a policy before directing all teachers to do it should be done in the future to avoid them become targets of frequent rule change. 


\section{Conclusions}

Based on the findings of this research, it can be concluded that even though the process of attitude assessment had been implemented in the schools under study, the teachers still found the difficulty to deal with it. They were overwhelmed by the many instruments in the attitude aspect. Consequently, they preferred to use more of the observation and journal in the attitude assessment compared to self- or peer-assessments. In addition, they also did not have sufficient time to assess each student in one day. Thus, with the various and numerous instruments, they were hampered with the increasing efforts and time that are needed just to process the students' attitude assessment. And this goes without saying about the other additional changes and workloads in the learning system. Parents, who were not cooperative in assisting their children's attitude progress, were also an obstacle for these teachers in implementing the attitude assessment as required by CR 2013. In spite of the fact that the teachers were obliged to keep on executing the authentic assessments, they expect that the assessment processes of CR 2013 can be simplified in the future to ease its implementation for teachers.

\section{References}

1. S. Nasution, Asas-asas kurikulum (Bumi Aksara, Jakarta, 2011)

2. Y. Abidin, Sistem pembelajaran dalam konteks Kurikulum 2013 (Refika Aditama, Bandung, 2014)

3. H. E. Mulyasa, Implementasi Kurikulum Tingkat Satuan Pendidikan: kemandirian guru dan kepala sekolah (Bumi Aksara, Jakarta, 2013)

4. Kunandar, Penilaian autentik (penilaian hasil belajar peserta didik berdasarkan kurikulum 2013) suatu pendekatan praktis edisi revisi (PT Raja Grafindo Persada, Jakarta, 2014)

5. G. Wiggins, The case for authentic assessment. Practical Assessment, Research \& Evaluation, 2(2), 1-3, 1990. Retrieved from http://pareonline.net/getvn.asp? v=2\&n=2

6. F. Alawiyah, Kesiapan guru dalam implementasi Kurikulum 2013. Jurnal Info Singkat Kesejahteraan Sosial DPR RI, 6(15), 9-12, 2014.

7. S. Maghfirah, Kendala guru pada penerapan penilaian autentik dalam pembelajaran Eksponen dan Logaritma di Kelas X SMA Negeri 1 Banda Aceh tahun pembelajaran 2014/2015 (Thesis, Universitas Syiah Kuala, Banda Aceh, 2015)

8. F. Eliza, Kendala guru Matematika terhadap penilaian otentik pada Kurikulum 2013 di SMA Negeri Kota Meulaboh Tahun Pelajaran 2014/2015 (Thesis, Universitas Syiah Kuala, Banda Aceh, 2015)

9. R. Handayani, Kendala guru Matematika dalam menyusun Rencana Pelaksanaan Pembelajaran (RPP) di SMP Kota Banda Aceh (Thesis, Universitas Syiah Kuala, Banda Aceh, 2014).

10. A. S. Bhakti, S. Kusairi, Muhardjito, Pengembangan model penilaian autentik berbasis Kurikulum 2013. Retrieved from http://jurnalonline.um.ac.id/data/artikel/artikel2B5157FBA171A8046A 8FBCAD73267BA6.pdf 2014

11. M. B. Miles, A. M. Huberman, Qualitative data analysis : an expanded source book (2nd edition) (Sage, Thousand Oaks, 1994)

12. M. Muslich, Authentic assessment: penilaian berbasis kelas dan kompetensi (Refika Aditama, Bandung, 2011) 